\title{
PAPERS
}

\section{Eradicating Helicobacter pylori reduces hypergastrinaemia during long term omeprazole treatment}

\author{
A El-Nujumi, C Williams, J E Ardill, K Oien, K E L McColl
}

Hypergastrinaemia is a well recognised side effect of treatment with proton pump inhibitor drugs. ${ }^{1}$ This occurs due to the marked suppression of gastric acid secretion and thus removal of the acid mediated inhibition of gastrin release. ${ }^{23}$ The clinical significance of such hypergastrinaemia in patients requiring long term proton pump inhibitor treatment is unclear.

In rats, long term omeprazole treatment is associated with argyrophil cell hyperplasia within the oxyntic mucosa ${ }^{4-6}$ and the development of gastric carcinoid tumours in up to $30 \%$ of female animals. ${ }^{78}$ These changes in the rats have been shown to be a consequence of the drug induced hypergastrinaemia. ${ }^{9}$ In man, long term treatment with omeprazole also results in argyrophil cell hyperplasia which correlates with the degree of hypergastrinaemia. ${ }^{10}{ }^{11}$ Gastrin also exerts trophic effects on gastric and colonic mucosa and on certain carcinoma cell lines derived from these tissues. ${ }^{12} 13$ The possible role of hypergastrinaemia in the development and growth of certain gastrointestinal tumours is uncertain but continues to attract research interest. ${ }^{14} 15$ Due to the uncertainty about the clinical significance of long term hypergastrinaemia in man, it would seem prudent to minimise the disruption of gastrin physiology induced by proton pump inhibitor drugs if possible.

Another common cause of chronic hypergastrinaemia in humans is $\mathrm{H}$ pylori infection, ${ }^{16}$ which is present in about $50 \%$ of the adult population. ${ }^{17}$ There is little information concerning the influence of $H$ pylori status on the gastrin response to proton pump inhibitor treatment. In the present study, we have examined this and in particular assessed whether eradicating $H$ pylori infection prior to commencing omeprazole treatment could be a means of reducing the hypergastrinaemia during subsequent proton pump inhibitor treatment.

\section{Materials and methods}

PATIENTS

Thirty three patients ( 22 males, mean age 40 years, range 22-60) with endoscopically confirmed peptic ulcer disease and/or oesophagitis entered the randomised study. Each of the patients had evidence of $H$ pylori infection confirmed by microscopy of antral biopsy specimens. 
STUDY DESIGN

On entry to the study all patients had their serum gastrin concentration assessed while fasting and in response to a standardised meal. $\mathrm{A}^{14} \mathrm{C}$ urea breath test was performed simultaneously. Any acid inhibitory drugs were stopped at least four weeks prior to this assessment. Following this they were randomised to receive either $H$ pylori eradication treatment consisting of three weeks treatment with tripotassium dicitratobismuthate $120 \mathrm{~g}$ three times daily, metronidazole $400 \mathrm{mg}$ three times daily, and amoxycillin 250 mg three times daily plus Gastrocote (alginic acid, aluminium hydroxide, magnesium trisilicate, and sodium bicarbonate; Boehringer Mannheim, Livingstone, UK) as required for symptoms, or Gastrocote alone. Four weeks after completing this treatment all patients had repeat serum gastrin studies and ${ }^{14} \mathrm{C}$ urea breath test and endoscopic examination.

Subjects then received four weeks treatment with omeprazole $40 \mathrm{mg} /$ day followed by six months treatment with omeprazole $20 \mathrm{mg} /$ day. Omeprazole was taken before breakfast. During the final week of the seven month course of omeprazole, the serum gastrin measurements and endoscopic examination were repeated. The proton pump inhibitor was then stopped and patients maintained if required on Gastrocote for four weeks before having a further ${ }^{14} \mathrm{C}$ urea breath test.

COMBINED ${ }^{14} \mathrm{C}$ UREA BREATH TEST AND GASTRIN ASSESSMENT

Patients reported between 09.00 and 10.00 hours following an overnight fast. Subjects cleaned their teeth and an intravenous cannula was inserted. Three $20 \mathrm{ml}$ venous blood samples were obtained at 15 minute intervals for fasting gastrin determination. A breath sample was collected for baseline ${ }^{14} \mathrm{C}^{\mathrm{CO}_{2}}$ determination. The subjects then drank, over five minutes,

$250 \mathrm{ml}$ Ensure Plus (Abbott Labs Ltd, Maidenhead, UK) which contains $1.25 \mathrm{MJ} /$ $200 \mathrm{ml}, 12.5 \mathrm{~g}$ protein, $40 \mathrm{~g}$ carbohydrate, $10 \mathrm{~g}$ fats, and vitamins (including vitamin $\mathrm{A}$, vitamin $\mathrm{D}$, vitamin $\mathrm{K}$, vitamin $\mathrm{C}$, vitamin $\mathrm{E}$, folic acid, and vitamins $B_{1}, B_{2}$, and $B_{6}$ ) plus elements of sodium, potassium, and calcium.

Immediately following this they drank 100 $\mathrm{ml}$ water containing $0.4 \mathrm{MBq}{ }^{14} \mathrm{C}$ urea. Additional $20 \mathrm{ml}$ blood samples for serum gastrin were obtained at 15 minute intervals for 90 minutes. A further breath sample for ${ }^{14} \mathrm{CO}_{2}$ determination was obtained at 20,40, and 100 minutes following administration of the ${ }^{14} \mathrm{C}$ $\mathrm{CO}_{2}$.

When the combined gastrin/breath tests were performed at the end of the omeprazole treatment periods, the omeprazole medication was taken that morning two hours prior to commencing the test.

ENDOSCOPIC EXAMINATION

During each endoscopic examination three biopsy specimens were taken from the antrum of the stomach for histology, rapid urease test ${ }^{18}$ (CLO test, Delta West Pty Ltd, Bentley, Australia) for $\mathrm{H}$ pylori, and culture for $\mathrm{H}$ pylori.
COMPLIANCE

Compliance with the omeprazole treatment schedule was assessed by performing capsule counts at each visit. Compliance was considered unacceptable if more than $25 \%$ of the total tablets were not taken over the treatment period.

ANALYSES

Serum gastrin concentration was measured by radioimmunoassay using antibody $\mathrm{R} 98$ which detects G17 and G34 with similar affinity. ${ }^{19}$ Fasting gastrin was calculated as the median of the three samples obtained at 15 minute intervals prior to commencing the meal. The meal stimulated gastrin was calculated as the median of the three samples obtained at 15,30, and 45 minutes. This time was chosen as it represented the time showing the maximal gastrin response to the meal.

Gastric biopsy specimens were transported to the laboratory in $0.9 \%$ sterile saline and cultured within four hours. ${ }^{20}$ The biopsy specimens were homogenised and inoculated on to a blood agar base no. 2 (Oxoid) agar plate ${ }^{21}$ containing $10 \% \mathrm{vol} / \mathrm{vol}$ horse blood and Skirrows selective supplement (Oxoid). The plates were incubated for 72 hours at $37^{\circ} \mathrm{C}$ in a microaerophilic atmosphere (BBL Campypak). Typical colonies which were oxidase and urease positive were identified as $H$ pylori.

Antral mucosal biopsy specimens for histological assessment were fixed in formalin, embedded in paraffin wax, and $4 \mu \mathrm{m}$ sections obtained. Sections at three levels were stained with haematoxylin and eosin for assessment of the presence or absence of gastritis. One section was stained using cresyl fast violet for assessment of $H$ pylori colonisation.

\section{STATISTICS}

The statistical significance of changes following the various treatments within each group was assessed by the Wilcoxon paired samples ranking test. The statistical significance of differing responses between the $H$ pylori eradicated and non-eradicated groups was assessed by the Wilcoxon rank sum test.

ETHICS

The study was approved by the West Glasgow Hospitals University NHS Trust Ethics Committee.

\section{Results}

Of the thirty three patients randomised, poor compliance with the omeprazole treatment or failure to attend for examination resulted in 12 patients being excluded from the final analysis. Of the 21 patients who completed the study, 10 were randomised to $H$ pylori eradication treatment and nine of them were $H$ pylori negative when reassessed four weeks following discontinuation of the treatment. Each of those nine had a 20 minute ${ }^{14} \mathrm{C}$ urea breath test value of less than $14 \mathrm{~kg}$ percentage dose $/ \mathrm{mmol} \mathrm{CO}_{2} \times$ 100, a negative antral CLO test, no $H$ pylori on microscopy, and negative culture of antral biopsy specimens. The one patient who was still positive had a 20 minute ${ }^{14} \mathrm{C}$ urea breath 
test value of more than 362, positive antral CLO test, and positive microscopy and culture of antral biopsy specimens. Of the 11 subjects who completed the study and received only symptomatic treatment, all remained positive for $H$ pylori one month post-treatment by each of the above tests.

ENDOSCOPIC FINDINGS

Of the nine patients in whom $H$ pylori was subsequently eradicated, their endoscopic diagnoses on initial presentation included duodenal ulceration in five, oesophagitis in three, and duodenal ulceration plus oesophagitis in one. The only endoscopic abnormality in those patients at one month after triple therapy was mild oesophagitis in one patient. One patient in whom the triple therapy failed to eradicate $H$ pylori, had duodenal ulceration but showed complete healing one month after triple therapy.

Of the 11 patients who received symptomatic treatment, endoscopic findings at initial presentation included duodenal ulceration in seven, prepyloric ulceration in two, oesophagitis in one, and duodenal ulceration plus oesophagitis in one. On reassessment, after two months symptomatic treatment alone, endoscopic examination showed duodenal ulceration in four, oesophagitis in two, prepyloric ulceration in two, and duodenal ulcer and gastritis in one; two patients showed no persisting abnormality.

Endoscopic examination was normal in each of the subjects reassessed after six months treatment with omeprazole $20 \mathrm{mg}$ per day.

H PYLORI ASSESSMENT DURING OMEPRAZOLE TREATMENT

Of the nine patients in whom $H$ pylori was successfully eradicated when examined one month after triple therapy, all had negative antral CLO tests, negative antral culture, and negative histology for $H$ pylori when reassessed after seven months of omeprazole treatment.

Of the 12 patients who were $H$ pylori positive after symptomatic or triple therapy, three had both negative antral CLO test and no evidence of $H$ pylori on microscopy of antral biopsy specimens; two of these patients showed resolution of antral gastritis after seven months of omeprazole therapy. One further patient had no evidence of $H$ pylori on antral microscopy. Seven of them were negative for $H$ pylori on culture.

The ${ }^{14} \mathrm{C}$ urea breath tests performed four weeks after completing the seven months of omeprazole treatment were negative in all those initially eradicated of the infection by triple therapy and positive in all those who had unsuccessful triple therapy or symptomatic treatment.

SERUM GASTRIN

On initial presentation prior to treatment with triple/symptomatic therapy, the patients in whom $H$ pylori was subsequently eradicated had similar fasting (median $54 \mathrm{ng} / \mathrm{l}$, range 17-226) and meal stimulated serum gastrin concentrations (median $114 \mathrm{ng} / \mathrm{l}$, range 31286) compared with the patients in whom the infection was not subsequently eradicated

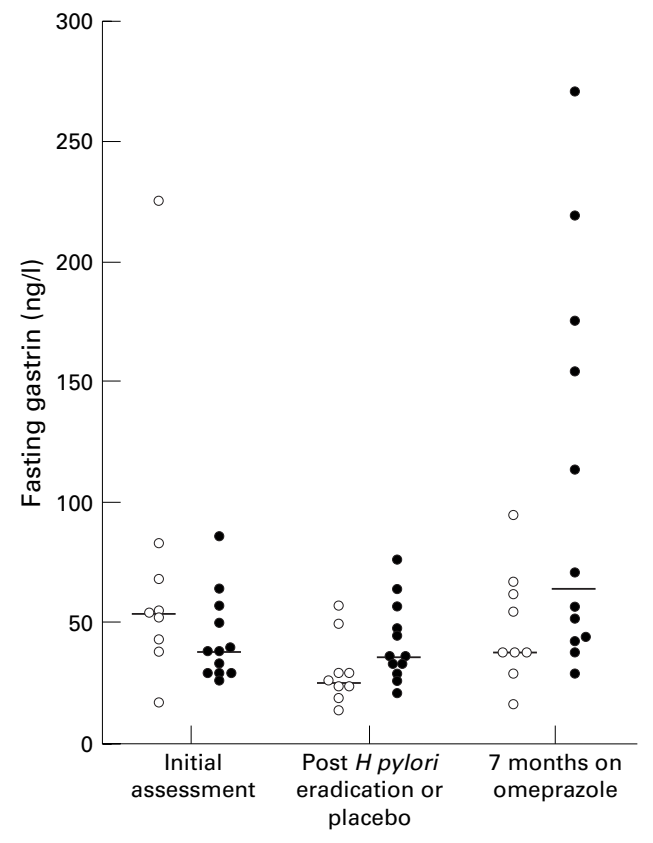

Figure 1 Fasting serum gastrin concentrations on initial assessment when all subjects were $H$ pylori positive, following randomisation to $H$ pylori eradication or no eradication, and following subsequent seven months' treatment with omeprazole. Subjects who had H pylori eradicated prior to omeprazole are represented by open circles.

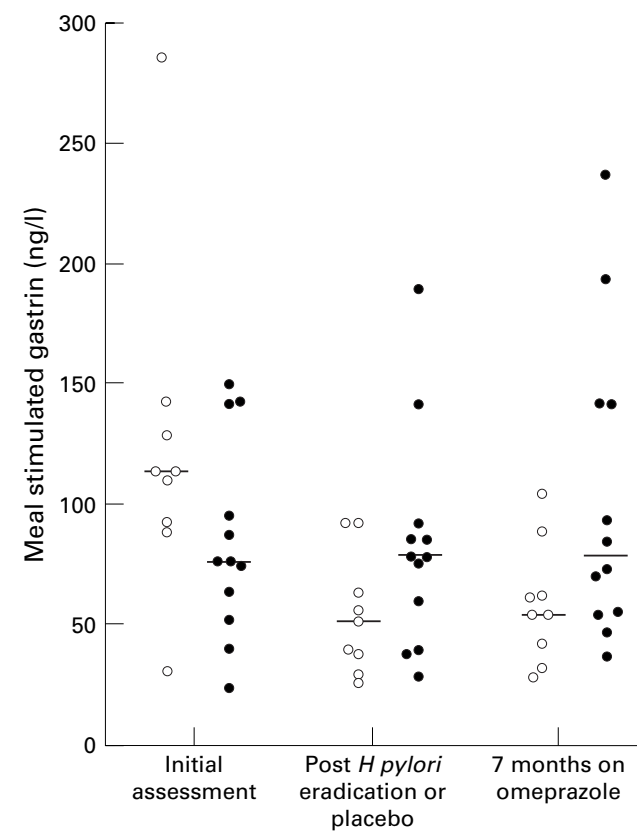

Figure 2 Meal stimulated gastrin concentrations on initial assessment when all subjects were $H$ pylori positive, following randomisation to $H$ pylori eradication or no eradication, and following subsequent seven months' treatment with omeprazole. Subjects who had H pylori eradicated prior to omeprazole are represented by open circles.

(fasting median $38 \mathrm{ng} / \mathrm{l}$, range 26-86; meal stimulated median $76 \mathrm{ng} / \mathrm{l}$, range $24-150$ ) (figs 1 and 2).

On reassessment at one month following failed triple therapy or symptomatic treatment there was no change in fasting or meal stimulated gastrin concentrations. In contrast, in the patients in whom $H$ pylori was eradi- 
H pylori eradicated

H pylori not eradicated

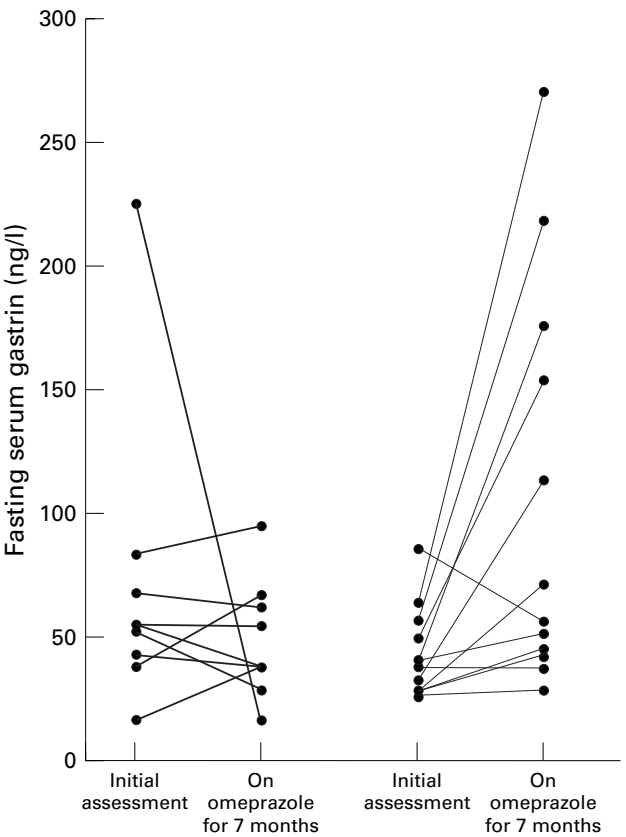

Figure 3 Fasting serum gastrin concentrations at initial assessment and after seven months omeprazole in subjects in whom $H$ pylori was and was not eradicated prior to commencing proton pump inhibitor treatment.

cated, median fasting gastrin fell by $48 \%$ and meal stimulated gastrin by $46 \%(\mathrm{p}<0.01$ for each) (figs 1 and 2).

In the patients in whom $H$ pylori was not eradicated, median fasting gastrin at the end of seven months of omeprazole treatment was $56 \%$ higher than that immediately prior to omeprazole $(p<0.005)$ although median meal stimulated gastrin was only $1 \%$ higher (not statistically significant). Likewise, in the patients in whom $H$ pylori was eradicated, median fasting gastrin at the end of the seven months of omeprazole was $56 \%$ higher than that immediately prior to starting omeprazole, although meal stimulated gastrin was only $4 \%$ higher (not statistically significant) (figs 1 and 2).

Compared with values at initial assessment (before anti-H pylori or symptomatic treatment), the median fasting gastrin concentration in those in whom $H$ pylori was not eradicated was increased by $26 \mathrm{ng} / \mathrm{l}$ after seven months of omeprazole treatment $(p<0.005)$, representing an increase of $68 \%$. In contrast, in patients in whom $H$ pylori was eradicated before omeprazole treatment, the fasting gastrin concentration was decreased by $12 \mathrm{ng} / \mathrm{l}$ after seven months omeprazole; this was not significantly different and represented a fall of $22 \%$ (fig 3). In the patients in whom $H$ pylori was not eradicated, median postprandial gastrin concentration after seven months omeprazole was similar to that on initial presentation. In the patients in whom $H$ pylori was eradicated before omeprazole treatment, median postprandial gastrin concentration after seven months omeprazole was $59 \mathrm{ng} / \mathrm{l}$ lower than on initial presentation, representing a $52 \%$ decrease $(\mathrm{p}<0.05)$ (fig 4$)$.

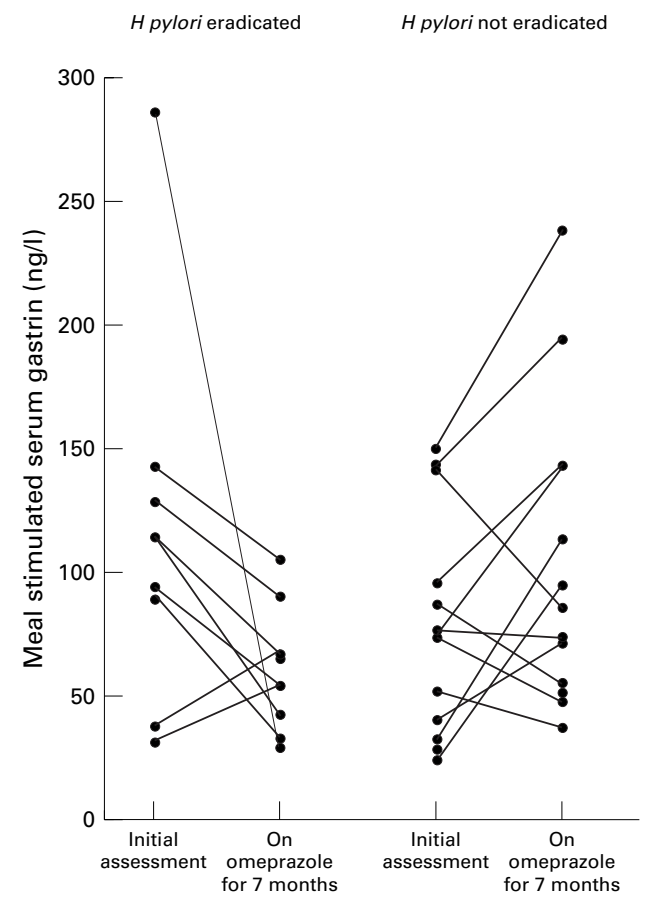

Figure 4 Meal stimulated gastrin concentrations at initial assessment and after seven months omeprazole in subjects in whom $H$ pylori was and was not eradicated prior to commencing proton pump inhibitor treatment.

Using the initial values (before anti- $H$ pyloril symptomatic therapy) as baseline, the change in gastrin following the seven month course of omeprazole was different in those in whom $H$ pylori was subsequently eradicated than in those in whom it was not eradicated with respect to both fasting gastrin $(p<0.03)$ and meal stimulated gastrin $(\mathrm{p}<0.01)$ (figs 5 and 6 ).

Median fasting gastrin during omeprazole treatment was higher in those in whom $H$ pylori

$H$ pylori not eradicated $H$ pylori eradicated
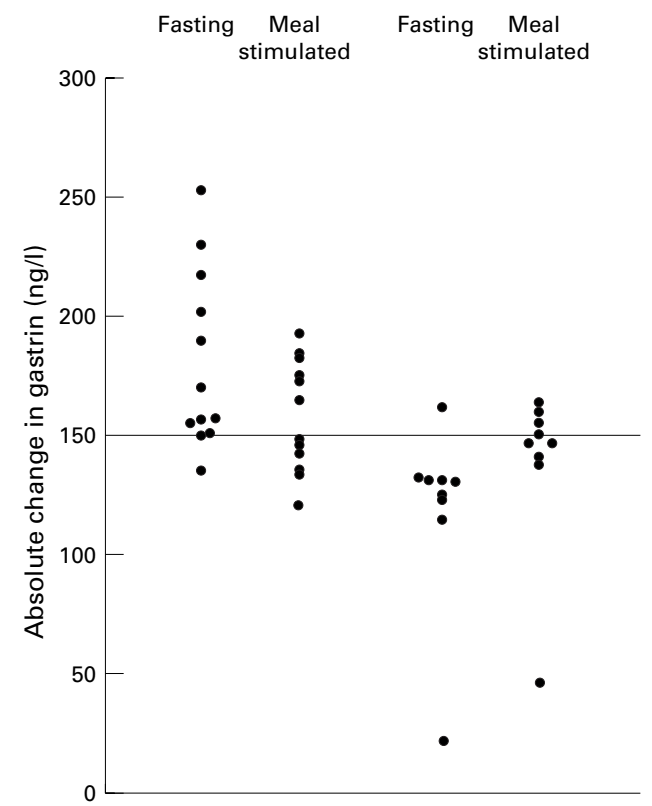

Figure 5 Absolute change in serum gastrin concentration between initial assessment and end of seven months omeprazole in subjects in whom $H$ pylori was or was not eradicated prior to proton pump inhibitor treatment. 
$H$ pylori not eradicated $H$ pylori eradicated

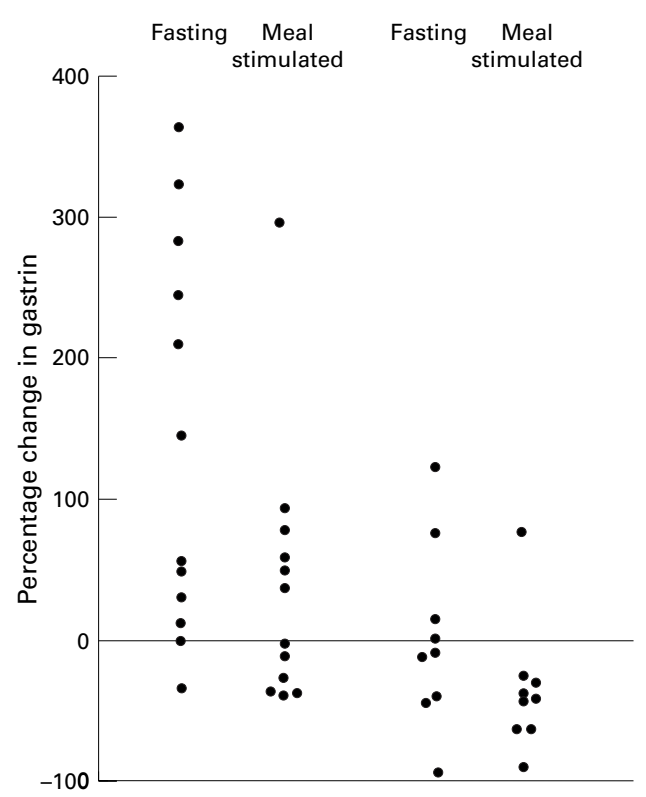

Figure 6 Percentage change in serum gastrin concentrations at initial assessment and after seven months omeprazole in subjects in whom H pylori was and was not eradicated prior to commencing proton pump inhibitor treatment.

was not eradicated (64 ng/l, range 29-271) than in those in whom it was eradicated (38 ng/l, range 17-95) though this did not quite reach conventional statistical significance $(\mathrm{p}<0.08)$. Likewise, the median meal stimulated gastrin during omeprazole treatment was higher in those in whom $H$ pylori was not eradicated (79 $\mathrm{ng} / \mathrm{l}$, range $38-238)$ than in those in whom it was eradicated $(55 \mathrm{ng} / \mathrm{l}$, range 29-105), though again this did not quite reach statistical significance $(\mathrm{p}<0.08)$.

\section{Discussion}

Proton pump inhibitor drugs and $H$ pylori infection are both important causes of hypergastrinaemia. ${ }^{16}$ Due to the high prevalence of $H$ pylori infection, a considerable proportion of subjects prescribed long term proton pump inhibitor treatment will be $H$ pylori positive and there is therefore interest in the combined effects of the two on serum gastrin. The present study indicates that $H$ pylori infection and proton pump inhibitor treatment have an additive effect on serum gastrin. This observation is consistent with our previous study with five days treatment with another proton pump inhibitor, pantoprazole. ${ }^{22}$ Our findings are also consistent with studies prior to the recognition of $H$ pylori which noted that subjects with higher pretreatment gastrin, probably related to $H$ pylori infection, also had higher values during omeprazole treatment. ${ }^{23}{ }^{24}$ The present study also shows that eradicating $H$ pylori infection is a means of reducing the rise in gastrin during subsequent proton pump inhibitor treatment.

Though both $H$ pylori infection and proton pump inhibitor treatment cause hypergastrinaemia, the present study indicates that they differ in the degree to which they raise fasting and meal stimulated gastrin concentrations. Eradication of $H$ pylori infection was associated with a more profound fall in meal stimulated than fasting gastrin concentrations and this is consistent with many previous studies showing that the infection predominantly increases meal stimulated gastrin concentrations. ${ }^{25}$ In contrast, in the present study, proton pump inhibitor treatment resulted in a greater percentage rise in fasting gastrin concentrations than meal stimulated concentrations and this was apparent in both $H$ pylori positive and $H$ pylori eradicated subjects. The relative efficacy of omeprazole and $H$ pylori in raising meal stimulated gastrin concentrations explains how the combination of omeprazole plus $H$ pylori eradication actually lowered meal stimulated gastrin, the $H$ pylori eradication gastrin lowering effect being greater than the omeprazole gastrin elevating effect. The reason for omeprazole having a more marked effect on fasting than meal stimulated gastrin may be explained by the difference in fasting and fed intragastric $\mathrm{pH}$. Fasting $\mathrm{pH}$ is usually considerably less than 3 and at this intragastric acidity gastrin release is inhibited. ${ }^{26}$ Omeprazole usually raises fasting $\mathrm{pH}$ above 4, thus disinhibiting gastrin release. ${ }^{27}$ Following a meal intragastric $\mathrm{pH}$ may already be above $\mathrm{pH} 4$ due to the buffering effect of the food and thus gastrin release will already be disinhibited. Consequently, any additional increase in $\mathrm{pH}$ due to omeprazole may have relatively little effect on the postprandial gastrin level.

The resultant effect on gastrin of proton pump inhibitor treatment plus $H$ pylori infection will depend on the mechanism by which each independently produces hypergastrinaemia. As stated above, the former is thought to cause hypergastrinaemia by removing the inhibition of gastrin release exerted by low intragastric $\mathrm{pH}^{2}{ }^{3}$ Hypergastrinaemia associated with $H$ pylori infection is thought to be secondary to depletion of antral somatostatin which exerts paracrine inhibitory control on gastrin release by the antral G cells. ${ }^{28-30}$ Somatostatin is largely responsible for mediating the inhibition of gastrin release exerted by low intragastric acid $\mathrm{pH}^{31}$ and impaired inhibition of gastrin release at low $\mathrm{pH}$ occurs in the presence of $H$ pylori infection. ${ }^{32}$ Thus, both $H$ pylori infection and acid inhibitory therapy are thought to cause hypergastrinaemia by disrupting the inhibition of gastrin release normally exerted by gastric acid. If that is the case, it might be expected that acid inhibitory treatment would result in a greater percentage increase in gastrin in $H$ pylori negative subjects who start with their gastrin normally suppressed by acid than in $H$ pylori positive subjects in whom the infection has already disinhibited gastrin release. However, in our present study we found that the percentage increase in gastrin during omeprazole treatment was at least as great in the presence versus absence of $H$ pylori infection. This disparity may be explained by additional factors influencing the combined effect of $H$ pylori plus omeprazole on serum gastrin. 
The first of these additional factors is the recent observation that the degree of elevation of intragastric $\mathrm{pH}$ caused by omeprazole is dependent on $H$ pylori status. Verdu et al ${ }^{33} 34$ observed that omeprazole $20 \mathrm{mg}$ /day raised daytime $\mathrm{pH}$ from 1.3 to 5.4 in $H$ pylori positive subjects but from 1.4 to only 2.9 in $H$ pylori negative subjects. Likewise, it raised night-time $\mathrm{pH}$ from 1.1 to 4.7 in $H$ pylori positive subjects, but from 1.1 to only 1.9 in $H$ pylori negative subjects. The mechanism by which $H$ pylori infection accentuates the antacid effects of omeprazole is unclear. However, it is known that there is an increase in severity of corpus gastritis $^{35}$ in $H$ pylori positive subjects during omeprazole treatment and this may impair the acid secreting capacity of the oxyntic mucosa. Whatever its mechanism, this accentuated $\mathrm{pH}$ elevation produced by omeprazole in $H$ pylori positive subjects will result in more complete disinhibition of gastrin release.

Recent studies indicate that there is progression of corpus atrophy during long term proton pump inhibitor treatment in $H$ pylori positive subjects which does not occur in uninfected subjects. ${ }^{36}{ }^{37}$ The development of atrophy during longer term omeprazole treatment will further reduce intragastric acidity and consequently further increase gastrin concentrations in $H$ pylori positive subjects.

Another factor influencing the combined effect of omeprazole and $H$ pylori on gastrin is the observation that omeprazole treatment reduces the density of the infection present in the gastrin producing antral region of the stomach..$^{35} 39$ In the present study, $H$ pylori infection was cleared from the antral mucosa by omeprazole in approximately one third of subjects. This suppression of $H$ pylori in the antral region by omeprazole will tend to reduce hypergastrinaemia by reducing the $H$ pylori induced hypergastrinaemia. This may explain the variations in degree of hypergastrinaemia seen in $H$ pylori positive subjects during treatment with omeprazole.

Although the interacting mechanisms involved in the combined effects of $H$ pylori and omeprazole on gastrin are complex, the present study shows that eradicating $H$ pylor $i$ is a means of reducing the rise in gastrin during subsequent omeprazole treatment. In view of the uncertainty about some of the possible long term sequelae of hypergastrinaemia in man, it may be appropriate to screen for $H$ pylori prior to commencing long term proton pump inhibitory treatment and eradicate it when present. A similar policy has recently been advocated in order to prevent the development of corpus atrophy during long term proton pump inhibitory treatment. ${ }^{36}{ }^{37}$ Whether such a policy will also reduce the clinical efficacy of the proton pump inhibitor due to reducing its $\mathrm{pH}$ elevating effect is unknown.

This study was supported by a grant from Astra Pharmaceuticals Ltd. This work was presented at the American Gastroenterology Association meeting in May 1996 and published in abstract form in Gastroenterology (1996;110:A102). The authors are grateful to the staff of Nuclear Medicine who performed the ${ }^{14} \mathrm{C}$ urea breath tests.
1 Koop H, Klein M, Arnold R. Serum gastrin levels during ong-term omeprazole treatment. Aliment Pharmacol Ther long-term om

2 Banerjee S, El-Omar E, Mowat A, et al. Sucralfate suppresses Helicobacter pylori infection and reduces acid secretion by $50 \%$ in patients with duodenal ulcer. Gastroenterology 1996;170:717-25.

3 Lind T, Cederberg C, Idstrom JP, Lonroth H, Olbe L, Lundell L. 24-Hour intragastric acidity and plasma gastrin during long-term treatment with omeprazole or ranitidine in patients with reflux esophagitis. Scand $\mathcal{F}$ Gastroenterol 1991;26:620-6.

4 Creutzfeldt W, Stockmann F, Conlon JM, Folsch UR, Bonatz $G$, Wulfrath $M$. Effect of short and long-term feeding of omeprazole on rat gastric endocrine cells. Digestion 1986;35(suppl 1):84-97.

5 Larsson H, Carlsson E, Hakanson R, et al. Time course of development and reversal of gastric endocrine cell hyperplasia after inhibition of acid secretion. Studies with omeprazole and ranitidine in intact and antrectomized rats. omeprazole and ranitidine in intact
Gastroenterology 1988;95:1477-86.

6 Koop H, Willemer S, Steinbach F, Eissele R, Tuch K, Arnold R. Influence of chronic drug-induced achlorhydria by substituted benzimidazoles on the endocrine stomach of rats. Gastroenterology 1987;92:406-13.

7 Ekmann L, Hansson E, Havu N, Carlsson E, Lundberg C. Toxicological studies on omeprazole. Scand $\mathcal{F}$ Gastroenterol 1985;20(Suppl.108):53-69.

8 Betton GR, Dormer CS, Wells T, Pert P, Price CA, Buckley P. Gastric ECL-cell hyperplasia and carcinoids in rodents following chronic administration of $\mathrm{H}_{2}$-antagonists SK\&F 93479 and oxmetidine and omeprazole. Toxicol Pathol 1988;16:288-98.

9 Eissele R, Patberg H, Koop H, et al. Effect of gastrin receptor blockade on endocrine cells in rats during achlorhydria. tor blockade on endocrine cells in rats
Gastroenterology 1992;103:1596-601.

10 Creutzfeldt W, Lamberts R. Is hypergastrinaemia dangerous Creutzfeldt W, Lamberts R. Is hypergastrinaemia danger
to man? Scand $\mathcal{F}$ Gastroenterol 1991;180(suppl):179-91.

11 Lamberts R, Creutzfeld W, Struber HG, Brunner G, Solcia E. Long-term omeprazole therapy in peptic ulcer disease: gastrin, endocrine cell growth and gastritis. Gastroenterology 1993;104:1356-70.

12 Kusyk CJ, McNeil NO, Johnson LR. Stimulation of growth of a colon cancer cell line by gastrin. Am f Physiol 1986;25: 9597-601

13 Ishizuka J, Martinez J, Townsend CM, Thompson JC. The effect of gastrin on growth of human stomach cancer cells. Ann Surg 1992;215:528-35.

14 Watson SA, Steele RJC. Gastrin antagonists in the treatment of gastric cancer. Anticancer Drugs 1993;4:599-604.

15 Rehfeld JF. Gastrin and colorectal cancer; a never-ending dispute? Gastroenterology 1995;108:1307-9.

16 Chittajallu RS, Ardill JES, McColl KEL. The degree of hypergastrinaemia induced by Helicobacter pylori is the same in duodenal ulcer patients and asymptomatic volunteers. Eur f Gastroenterol Hepatol 1992;4:49-53.

17 Veldhuyzen van Zanten SJO, Pollak PT, Best LM, Bezanson GS, Marrie T. Increasing prevalence of Helicobacter pylori infection with age: continuous risk of infection in adults rather than cohort effect. F Infect Dis 1994;169:434-7.

18 Marshall BJ, Warren R, Francis GJ, Langton SR, Goodwin CS, Blincow ED. Rapid urease test in the management of Campylobacter pyloridis associated gastritis. Am f Gastroenterol 1987;82:200-10.

19 Mulholland G, Ardill JES, Fillmore D, Chittajallu RS, Fullarton GM, McColl KEL. Helicobacter pylori related arton GM, McColl KEL. Helicobacter pylori related hypergastrinaemia is the result
gastrin 17. Gut 1993;34:757-61.

20 Veenendaal RA, Lichtendal-Bernards AT, Pena AS, Endtz $\mathrm{HP}$, van Boven CP, Lamers CB. Effect of transport medium and transportation time on culture of Helicobacter pylori from gastric biopsy specimens. F Clin Pathol 1993;46:561-3.

21 Jones DM, Lessels AM, Eldridge J. Campylobacter-like organisms on the gastric mucosa: culture, histological and serological studies. F Clin Pathol 1984;37:1002-6.

22 McColl KEL, El Nujumi AM, Dorrian CA, Macdonald AMI, Fullarton GM, Harwood J. Helicobacter pylori and hypergastrinaemia during proton pump inhibitor therapy. Scand f Gastroenterol 1992;27:93-8.

23 Koop H, Klein M, Arnold R. Serum gastrin levels during long-term omeprazole treatment. Aliment Pharmacol Ther 1990;4:131-8.

24 Jansen JBMJ, Klinkenberg-Knol EC, Meuwissen SGM, et al. Effect of long-term treatment with omeprazole on al. Effect of long-term treatment with omeprazole on patients with reflux esophagitis. Gastroenterology 1990;99: patients

25 McColl KEL, Fullarton GM, Chittajallu R, et al. Plasma gastrin, daytime intragastric $\mathrm{pH}$, and nocturnal acid output before and at 1 and 7 months after eradication of Helicobacter pylori in duodenal ulcer subjects. Scand $\mathcal{f}$ Gastroenterol 1991;26:339-46.

26 Penston JG, Dixon JS, Selway SAM, Wormsley KG. Gastric histology and plasma gastrin response to a meal in patients with duodenal ulcer disease after five years treatment with ranitidine. Aliment Pharmacol Ther 1990;4:381-92.

27 Lind T, Cederberg C, Idstrom J P, Lonroth H, Olbe L, Lundell L. 24-Hour intragastric acidity and plasma gastrin during long-term treatment with omeprazole or ranitidine in patients with reflux esophagitis. Scand $\mathcal{f}$ Gastroenterol 1991;26:620-6.

28 Odum D, Petersen HD, Andersen IB, Hansen BF, Rehfeld JF. Gastrin and somatostatin in Helicobacter pylori infected antral mucosa. Gut 1994;35:615-18. 
29 Kaneko H, Nakada K, Mitsuma T, et al. Helicobacter pylori infection induces a decrease in immunoreactive1992;37:409-16.

30 Moss SF, Legon S, Bishop AE, Polak JM, Calam J. Effect of Helicobacter pylori on gastric somatostatin in duodenal ulcer disease. Lancet 1992;340:930-2.

31 Lucey MR, Yamada T. Biochemistry and physiology of gastrointestinal somatostatin. Dig Dis Sci 1989;34:5S-13S

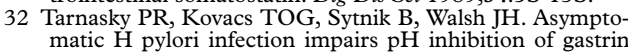
and acid secretion during second hour of peptone meal stimulation. Dig Dis Sci 1993;38:1681-7.

33 Verdu EF, Armstrong D, Fraser R, et al. Effect of Helicobacter pylori status on intragastric $\mathrm{pH}$ during treatment with omeprazole. Gut 1995;36:539-43.

34 Verdu E F, Armstrong D, Idstrom J-P, et al. Effect of curing Helicobacter pylori infection on intragastric $\mathrm{pH}$ during Helicobacter pylori infection on intragastric p
treatment with omeprazole. Gut 1995;37:743-8.
35 Logan RPH, Walker MM, Misiewicz JJ, Gummett PA, Karim QN, Baron JH. Changes in the intragastric distribution of Helicobacter pylori during treatment with omeprazole. Gut 1995;36:12-16

36 Kuipers EJ, Kinkenberg-Knol EC, Havu N, et al. Helicobacter pylori and development of atrophic gastritis during omeprazole maintenance therapy [abstract]. Gastroenterology 1995;108:A137.

37 Kuipers EJ, Lee A, Klinkenberg-Knol EC, Meuwissen SGM. Review article: the development of atrophic gastritisReview article: the development of atrophic gastritis-
Helicobacter pylori and the effects of acid suppressive therapy. Aliment Pharmacol Ther 1995;9:331-40.

38 Weil J, Bell DG, Powell K, et al. Omeprazole and Helicobacter pylori: temporary suppression rather than true eradication. Aliment Pharmacol Ther 1991;5:309-13.

39 Hui WM, Lam SK, Ho J, et al. Effect of omeprazole on duodenal ulcer-associated antral gastritis and Helicobacter pylori. Dig Dis Sci 1991;36:577-82. 